\title{
EKSTRAKSI DAN KARAKTERISASI PEKTIN DARI KULIT DAN DAMI BUAH CEMPEDAK (Artocarpus chempeden)
}

\section{Extraction and Characterization of Pectin from The Skin and Rags of Cempedak Fruit (Artocarpus chempeden)}

\author{
Nurhaeni $^{1}$, Nur A Atjiang ${ }^{1 *}$, Jaya Hardi ${ }^{1}$, Diharnaini ${ }^{1}$, Khairunnisa $^{1}$ \\ 1) Jurusan Kimia, Fakultas MIPA, Universitas Tadulako, Palu \\ J. Soekarno Hatta Km.9, Kampus Bumi Tadulako Tondo Palu, Telp. 0451- 422611 \\ *)Coresponding author: aisyahatjiang.lasawdi@gmail.com \\ Diterima 17 September 2018, Disetujui 22 November 2018
}

\begin{abstract}
A study about extraction and characterization of pectin from the peels and rags of Cempedak (Artocarpus chempedan) has been conducted. The aims of the research is to determine the best solvent and extraction time that required to resulting the highest yield of pectin. Completely Random Design (CRD) was used in this research with dependent variabel of solvent type (acid citric, acid hydrochloric and acid acetic) and extraction time of 30,60,90,120, and 150 minutes. The results showed that the best solvent was citric acid with pectin yields of $38.85 \%$. The best extraction time was achieved at 90 minutes with pectin yields of $34.65 \%$. Pectin form the peels and rags of Cempedak had water content of $5.5 \%$, metoxil content of $12.4 \%$; galacturonate of $71.6 \%$, and ash content of $6 \%$.
\end{abstract}

Keywords: Pectin, peels and rags of Cempedak, solvent type, extraction time

\begin{abstract}
ABSTRAK
Telah dilakukan ekstraksi dan karakterisasi pektin dari kulit dan dami buah Cempedak (Artocarpus chempedan) dengan tujuan untuk mengetahui jenis pelarut dan waktu ekstraksi terbaik yang diperlukan untuk menghasilkan rendemen pektin tertinggi. Penelitian dilakukan menggunakan rancangan acak lengkap (RAL) yang terdiri atas 2 faktor, yaitu jenis pelarut yang terdiri idar 3 taraf (asam sitrat, asam klorida, dan asam asetat) dan waktu eksraksi terdiri dari 5 taraf $(30,60,90,120$, dan 150 menit) yang masing-masing dilakukan sebanyak dua kali pengulangan. Hasil penelitian menunjukan jenis pelarut terbaik adalah asam sitrat dengan rendemen $38,85 \%$ dan waktu terbaik diperoleh pada waktu 90 menit dengan rendemen 34,65\%. Pektin yang diperoleh mengandung kadar air 5,5\%; kadar metoksil 12,4\%; kadar galakturonat $71,6 \%$; dan kadar abu $6 \%$.
\end{abstract}

Kata Kunci : pektin, kulit dan dami Cempedak, pelarut, waktu ekstraksi 


\section{LATAR BELAKANG}

Pektin bisa didapatkan dari semua tanaman yang berfotosintesis yang terletak dalam persimpangan zona antara sel-sel dengan dinding sekunder termasuk xilem dan sel-sel serat dalam jaringan kayu. Menurut O'Neil et al. (2014) pektin pada tanaman juga banyak terdapat pada lapisan kulit pada buah, seperti pektin dari kulit buah kluwih (Febriyanti et al., 2018), limbah kulit buah sukun (Madjaga et al., 2016), kulit buah pepaya (Nurviani, 2014), dan kulit buah coklat (Susilowati et al., 2013) telah banyak dijadikan sebagai sumber pektin. Ketersediaan bahan pangan yang lain masih memungkinkan untuk dijadikan sumber pektin. Mengingat kebutuhan pektin dibidang industri dan farmasi konsumsi pektin dunia dari tahun ke tahun semakin meningkat (Budiyanto dan Yulianingsih, 2008). Hal ini menjadi alasan bagi para ilmuan untuk menemukan sumber pektin yang lain, salah satunya adalah kulit dan dami buah cempedak.

Cempedak (Artocarpus champeden) merupakan salah satu tanaman yang dapat hidup di daerah beriklim tropis, seperti di Sulawesi Tengah khususnya di desa Labuan kabupaten Poso masih banyak terdapat tanaman cempedak tumbuh dengan subur dan memiliki kemampuan hidup tinggi walaupun berada di habitat yang kurang menguntungkan seperti di tepi sungai, tepi sawah, tepi jurang dan sebagainya. Buah cempedak yang dikonsumsi hanya daging buah saja sedangkan kulit dan dami cempedak hanya dibuang, sehingga konsumsi buah cempedak menghasilkan limbah berupa kulit dan dami buah cempedak yang belum dimanfaatkan secara optimal. Oleh karena itu, untuk meningkatkan nilai tambahnya, limbah kulit dan dami buah cempedak tersebut dapat dimanfaatkan sebagai sumber pektin.

Pektin dari bagian jaringan tanaman diekstrkasi dengan menggunakan pelarut yang bersifat asam (Nurhikmat, 2003). Beberapa jenis pelarut asam telah digunakan untuk memisahkan pektin, baik asam organik maupun anorganik. Jenis asam organik yang umumnya digunakan sebagai pengekstrak pektin ialah asam asetat, asam nitrat, dan asam sitrat, sedangkan asam anorganik meliputi asam natrium heksametafosfat, asam sulfat, dan asam klorida. Faktor-faktor yang mempengaruhi ekstraksi pektin, yaitu ukuran partikel, waktu ekstraksi, konsentrasi pelarut, suhu, jenis pelarut, dan $\mathrm{pH}$ (Fitriani, 2003).

Putra (2010) melaporkan bahwa pektin dari jerami nangka dapat diekstraksi dengan $\mathrm{HCl}$ pada suhu $85^{\circ} \mathrm{C}$ selama 3,5 jam dan pada $\mathrm{pH} 1,5$ menghasilkan kondisi yang optimumdan perbandingan jerami nangka dan cairan pengestrak 1:5 dengan rendemen 4,54\%, kadar metoksil $8,16 \%$ dan kadar anhidrogalakturonat $88,01 \%$. Margani et al. (2012), melaporkan penelitian tentang jenis pelarut dan lama ekstraksi dari limbah buah nangka diperoleh rendemen 
pada pelarut asam sitrat sebesar 10,21\% dan kadar metoksil 9,25\%, sedangkan pada pelarut asam klorida diperoleh rendemen $8,11 \%$. Pada penelitian ini digunakan pelarut asam sitrat dengan tujuan menghasilkan karakteristik pektin yang lebih baik.

\section{METODE PENELITIAN}

\section{Bahan dan Peralatan}

Bahan dasar yang digunakan dalam penelitian ini adalah kulit dan dami buah cempedak yang diperoleh dari desa Labuan Kab. Poso, asam sitrat 5\%, asam klorida 5\%, asam asetat 5\%, etanol $96 \%$, aquadest, kertas saring, aluminium foil, $\mathrm{NaOH}$, dan indikator PP.

Peralatan yang digunakan dalam penelitian ini adalah blender, pisau, ayakan 60 mesh, batang pengaduk, neraca analitik (Ohaus Corp. Pine Brook), viscosimeter ostwald, magnetik stirer, corong buchner, penangas air, stopwatch, termometer, oven (Memmert), desikator, statif dan klem, cawan porselen, spektrofotometri FTIR (Bruker) dan alat dan gelas yang umum digunakan di laboratorium kimia.

\section{Prosedur Penelitian}

\section{Preparasi Sampel Kulit dan Dami Buah Cempedak}

Kulit dan dami buah cempedak dicuci dan ditiriskan kemudian dijemur di bawah sinar matahari sampai kering, setelah kering kulit dihaluskan dengan menggunakan blender. Serbuk tepung kulit dan dami cempedak diayak dengan ayakan 60 mesh. Tepung kulit dan dami buah cempedak yang telah diayak selanjutnya digunakan pada ekstraksi pektin.

\section{Ekstraksi Pektin (Canteri-Scheim dalam Arviani, 2008)}

Sebanyak 10 gram sampel serbuk kulit dan dami buah cempedak masingmasing ditambahkan $500 \mathrm{ml}$ asam sitrat $5 \%$ diekstraksi didalam penangas dengan suhu $85^{\circ} \mathrm{C}$, selama 90 menit dengan kecepatan pengadukan 600rpm. Setelah diekstrasi, kemudian ekstrak disaring menggunakan kertas saring dengan bantuan penyaring vakum guna memisahkan ampas dan filtratnyaFiltrat yang diperoleh diuapkan pada suhu 90$95^{\circ} \mathrm{C}$ sampai volume mencapai setengahnya, selanjutnya didinginkan. Ditambahkan dengan etanol 96\% dan diendapkan selama 24 jam dalam suhu ruang dan dipisahkan antara filtrat dan residunya. Residu yang diperoleh selanjutnya dikeringkkan dengan oven pada temperatur $50^{\circ} \mathrm{C}$ selama 24 jam. Pektin dihaluskan diperoleh bubuk pectin.

\section{Uji kualitatif (Canteri-Scheim dalam Arviani, 2008)}

Uji kualitatif ini dilakukan dengan cara bubuk pektin ditimbang sebanyak 0,01 gram. Kemudian dimasukkan dalam tabung reaksi dan ditambahkan $1 \mathrm{ml}$ air. Campuran ekstrak pektin-air dalam tabung dipanaskan dalam penangas air selama 15 menit. Pengamatan gel yang kaku 
sebagai ciri adanya pektin dilakukan setelah campuran dingin.

Penentuan kadar air pektin (Ranganna, 2000)

Menimbang sebanyak 2 gram pektin, dipanaskan didalam oven pada suhu $105^{\circ} \mathrm{C}$ selama 2 jam, selanjutnya didinginkan dalam desikator dan ditimbang sampai diperoleh bobot yang tetap.

Kadar air $=\frac{(\mathrm{BC}+\mathrm{BS})-(\mathrm{BC}+\mathrm{BS})}{\mathrm{BS}} \times 100$

Penentuan kadar metoksil dan galakturonat (Akhmalludin, 2009)

Pektin kering yang diperoleh dianalisis kandungan metoksil dan galakturonatnya, dilakukan dengan cara melarutkan 0,25 gram pektin kering dengan $50 \mathrm{ml}$ air suling dan ditambahkan $1 \mathrm{ml}$ alkohol $70 \%$,kemudian dipanaskan dan diaduk sampai membentuk gel. Campuran didinginkan, ditambahkan 3 tetes indikator PP kemudian dititrasi dengan $0,05 \mathrm{~N} \mathrm{NaOH}$. Titik ekivalen ditandai dengan perubahan warna dari putih kecoklatan kemerah muda. Volume $\mathrm{NaOH}$ yang dibutuhkan dicatat $\left(\mathrm{V}_{1}\right)$, selanjutnya ditambahkan $10 \mathrm{ml} \mathrm{HCl} 1 \%$ dan dikocok, kemudian larutan didiamkan selama 15 menit. Larutan dikocok sampai warna merah muda hilang dan ditambahkan 3 tetes indikator PP serta titrasi dengan 0,05 N NaOH sampai timbul warna merah muda $\left(\mathrm{V}_{2}\right)$. Kadar galakturonat dan metoksil dihitung menggunakan persamaan :
Kadar galakturonat $=$

$$
\frac{(\mathrm{V} 1+\mathrm{V} 2) \mathrm{X} \mathrm{N} \text { X BM galakturonat }}{\text { Berat pektin } \times 1000} \times 100
$$

$\mathrm{BM}$ galakturonat $=176 \mathrm{gr} / \mathrm{mol}$

Kadar metoksil $=\frac{\mathrm{V} 2 \mathrm{X} \mathrm{N} \times \mathrm{BM} \text { metoksil }}{\text { Berat pektin } \times 1000} \times 100$

BM Metoksil $=31 \mathrm{gr} / \mathrm{mol}$

Penentuan kadar abu (Meilina, 2005 dalam Nurviani 2014)

Cawan porselin yang akan digunakan, dikeringkan dalam tanur. Pada suhu $60^{\circ} \mathrm{C}$ selama 3 jam.selanjutnya diidinginkan dalam desikator dan ditimbang. Pektin ditimbang sebnyak 1 gram kemudian dimasukkan kedalam tanur pada suhu $600{ }^{\circ} \mathrm{C}$ selama 6 jam kemudian didinginkan dalam desikator, perlakuan diulang hingga diperoleh bobot tetap. Kadar abu dihitung menggunakan persamaan :

Kadar abu $=\frac{\text { Bobot abu (gr) }}{\text { Berat pektin (gr) }} \times 100$

Identifikasi spektrum IR pektin dari kulit dan dami buah cempedak

Ditimbang serbuk kering $\mathrm{KBr}$ sebanyak 0,3 gram dan 0,015 gram pektin. Pektin dan serbuk $\mathrm{KBr}$ dicampurkan dan dikompresi dalam pellet press dengan kompresi hidrolik berkekuatan 10 torr yang dihubungkan dengan pompa vakum. Pelet campuran $\mathrm{KBr}$ dan sampel diletakkan diantara 2 celah yang dilewati berkas sinar inframerah. Diatur spektrumnya pada rentang bilangan gelombang 4000 - 400 
$\mathrm{cm}^{-1}$. Dianalisis dengan spektrofotometer FT-IR.

\section{HASIL DAN PEMBAHASAN}

\section{Pektin Hasil Ekstraksi Pada Berbagai Jenis Pelarut}

Ekstraksi dapat dilakukan dengan cara kimia, dimana pektin dapat diekstrak dari jaringan tanaman dengan menggunakan air panas dan asam yang berfungsi untuk menghidrolisis propektin menjadi pektin yang larut dalam air ataupun membebasakn pektin dari ikatan dengan senyawa lain misalnya selulosa. Metode ekstraksi yang telah dilakukan menggunakan larutan asam, yakni asam sitrat, asam klorida dan asam asetat dan pemisahannya menggunakan etanol. Penggunaan pelarut asam dikarenakan pada ekstraksi dalam kondisi asam cenderung mengakibatkan hidrolisis pada ikatan glikosidik gugus metil ester dari senyawa pektin untuk menghasilkan asam galakturonat (Smith dan Bryant, dalam Budiyanto dan Yulianingsih, 2008).

Jenis pelarut yang digunakan yaitu asam sitrat, asam klorida dan asam asetat. Hasil perhitungan diperoleh rendemen pektin tertinggi 38,85 \% pada pelarut asam sitrat dan rendemen pektin terrendah 0,185 \% pada pelarut asam klorida. Hasil pektin yang diperoleh berwarna putih kecoklatan.

Rendemen pektin dipengaruhi oleh tingkat keasaman suatu pelarut, dimana semakin besar tingkat keasaman suatu pelarut maka rendemen pektin akan semakin rendah. Asam sitrat merupakan pelarut terbaik untuk digunakan dalam ekstraksi pektin pada kulit dan dan dami buah cempedak dengan rendemen sebanyak 38,85\%. Hal ini dikarenakan asam sitrat merupakan asam organik lemah.

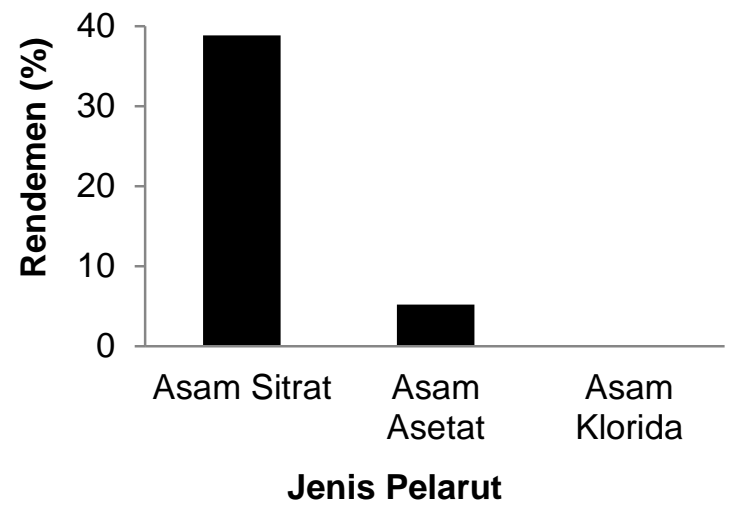

Gambar 1 Pengaruh Jenis Pelarut terhadap Rendemen Pektin

Asam bekerja pada ekstraksi pektin karena adanya atom hidrogen $(\mathrm{H})$ pada gugus karboksil $(-\mathrm{COOH})$ yang dilepaskan sebagai ion $\mathrm{H}^{+}$. Ion ini selanjutnya memutuskan ikatan protopektin dengan senyawa lain yang terdapat di dalam dinding sel tanaman.

Rendemen terendah sebanyak $0,185 \%$ didapatkan dari pelarut asam klorida. Hal ini dikarenakan asam klorida merupakan asam mineral sekaligus asam kuat. Dimana asam kuat tidak terlalu baik dalam mengekstrak pektin dibandingkan dengan asam organikl lemah (asam sitrat), karena hanya akan menghidrolisis pektin lebih lanjut menjadi asam pektat atau dapat mendegradasi struktur pektin secara berlebihan, sehingga rendemen 
yang dihasilkan lebih sedikit dan kadar air semakin tinggi (Ardiansyah et al., 2014).

Berdasarkan hasil analisis sidik ragam menggunakan SPSS dengan taraf kepercayaan 95\% $(\alpha=0,05)$ dihasilkan nilai sign ( $p$ value $)<$ alpha yang menunjukkan bahwa jenis pelarut tepung kulit dan dami buah cempedak berpengaruh nyata terhadap rendemen pektin yang dihasilkan, oleh karena itu dapat dilakukan analisis lanjut dengan uji Duncan untuk menentukan jenis pelarut terbaik tepung kulit dan dami buah cempedak. Hasil uji Duncan menunjukkan bahwa jenis pelarut asam sitrat, asam asetat dan asam klorida berbeda nyata. Dengan demikian, jenis pelarut asam sitrat yang memiliki rendemen tertinggi dapat direkomendasikan untuk diaplikasikan dalam ekstraksi pektin dari kulit dan dami buah cempedak.

Rendemen pektin dari hasil penelitian ini lebih tinggi dibandingkan dengan rendemen pektin Christianita (2014) pada ampas apel manalagi adalah 18,57\%, Nurviani (2014) pada kulit buah pepaya varietas semangka adalah $12,70 \%$ dan Putra (2010) pada dami buah nangka dari hasil penelitian yang ada antara lain $4,54 \%$. Perbedaan rendemen pektin yang diperoleh disebabkan oleh perbedaan sampel, pelarut asam dan konsentrasi asam yang digunakan. Rachmawan et al. (2005) melaporkan bahwa ekstraksi pektin dengan asam sitrat lebih baik dibanding asam klorida karena semakin tinggu kekuatan asam maka kecenderungan pektin terhidrolisis lebih lanjut semakin besar sehingga menurunkan rendemen pektin.

\section{Rendemen Pektin Pada Berbagai Waktu Ekstraksi}

Ekstraksi pektin tidak hanya dipengaruhi oleh jenis pelarut, tetapi juga dipengaruhi oleh waktu ekstraksi. Adapun jenis pelarut yang diterapkan adalah pelarut asam sitrat $5 \%$ yang merupakan pelarut terbaik dari perlakuan sebelumnya Penelitian ini menerapkan variasi waktu ekstraksi 30 menit, 60 menit, 90 menit, 120 dan 150 menit untuk mendapatkan rendemen pektin. Hasil rendemen pektin yang diperoleh yaitu 17,5\%;24,05\% ; $34,65 \% ; 27,75 \%$ dan 22,75 \% (Gambar 2). Dari hasil yang ditunjukan terlihat bahwa semakin lama waktu ekstraksi, berat pektin yang dihasilkan semakin besar, namun pada waktu ekstraksi 150 menit, berat pektin yang dihasilkan menurun. Hal ini disebabkan oleh waktu ekstraksi yang semakin lama. Menurut Evi et al. (2013) Semakin lama waktu ekstraksi maka semakin lama terjadi proses difusi pelarut ke dalam sel jaringan tanaman yang berarti semakin banyak jumlah zat terlarut yang terambil dari ampas wortel dan juga semakin banyak protopektin yang berubah menjadi pektin. Namun, waktu ekstraksi yang terlalu lama juga dapat menurunkan kadar pektin karena terdegradasi menjadi asam pektat.

Hasil analisis sidik ragam menggunakan SPSS dengan taraf 
kepercayaan $95 \%(\alpha=0,05)$ dihasilkan nilai signifikan $\left(\mathrm{p}_{\text {value }}\right)<$ alpha yang menunjukkan bahwa waktu ekstraksi berpengaruh nyata terhadap rendemen pektin yang dihasilkan. Oleh karena itu, untuk menentukan waktu ekstraksi terbaik dapat dilakukan analisis lanjut dengan uji Duncan. Hasil uji Duncan menunjukkan bahwa waktu ekstraksi 60 dan 150 menit berbeda tidak nyata karena berada pada subset yang sama, begitu pula dengan waktu ekstraksi 60 dan 120 menit berada pada kolom subset yang sama sehingga berbeda tidak nyata dan waktu ekstrasi 30 dan 90 menit berbeda nyata karena berada pada subset yang berbeda. Dengan demikian, waktu ekstraksi 90 menit dapat direkomendasikan untuk diaplikasikan dalam ekstraksi pektin dari tepung kulit dan dami buah cempedak.

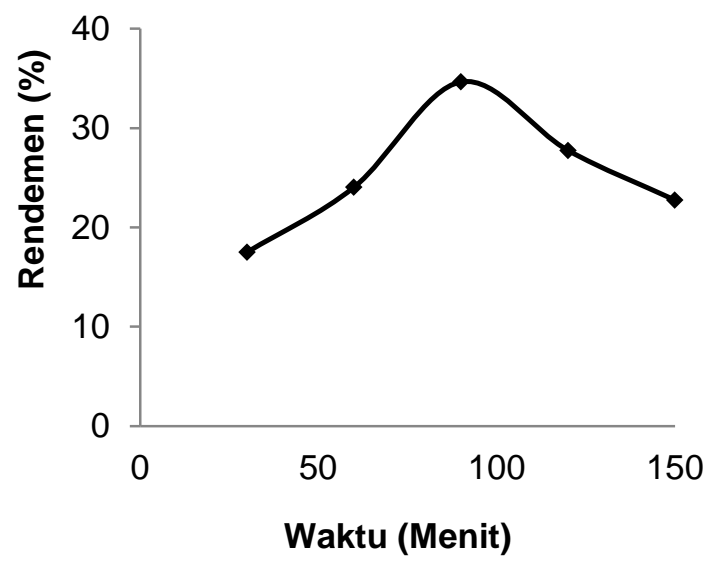

Gambar 2. Rendemen pektin terhadap pengaruh waktu ekstraksi

Rendemen hasil penelitian ini lebih tinggi dibandingkan dengan hasil rendemen pektin yang dilakukan oleh Putra (2010) tentang Pektin dami buah nangka pada waktu 210 menit adalah
4,54\%, Syamsudin dkk (2015), meneliti tentang pektin dari kulit buah nangka pada waktu 90 menit adalah 4,68\%, dan Windiarsih et al. (2015), meneliti tentang kajian waktu ekstraksi dan kosentrasi pelarut kulit buah nangka pada waktu 8,16 menit adalah 17,28\%. Perbedaan rendemen yang dihasilkan disebabkan oleh perbedaan sampel yang digunakan dan waktu ekstraksi. Waktu ektraksi pektin yang lebih lama menyebabkan difusi pelarut ke dalam jaringan tumbuhan semakin besar sehingga jumlah pektin yang dihasilkan semakin besar. Namun, pada penggunaan waktu ekstraksi yang terlalu lama mengakibatkan pektin terdegradasi lanjut menjadi asam pektat sehingga kadar pektin yang diperoleh juga menurun (Evi et al., 2013).

\section{Kelarutan Pektin dalam Air}

Untuk mengetahui apakah hasil ekstraksi itu adalah pektin, dilakukan uji kelarutan dalam air. Hasil yang diperoleh menunjukan ekstrak merupakan senyawa pektin. Ekstrak terlarut dalam air dan membentuk larutan kental seperti koloid Hal ini sesusai dengan sifat pektin yang larut dalam air dengan membentuk koloid.

\section{Kadar Metoksil}

Kadar metoksil didefinisikan sebagai gugus metil teresterifikasi pada ekstraksi kulit buah cempedak. Kadar metoksil berpengaruh terhadap kemampuan pembentukan gel yang baik. Kadar metoksil pektin tergolong tinggi jika memiliki nilai $\geq 7 \%$ (Goycoolea dan 
Adriana, 2003). Pektin dengan kadar metoksil tinggi umumnya dimanfaatkan pada pembuatan jeli buah, selai, puding, dan saus salad, sedangkan pektin dengan kadar metoksil yang rendah lebih banyak digunakan pada pembuatan gel karena memiliki stabilitas tinggi dan banyak pula dimanfaatkan sebagai penyalut (coating agent) pada berbagai produk olahan pangan (Pamona, 2013).

Berdasarkan hasil analisis kadar metoksil pada pektin kulit dan dami buah cempedak, didapatkan kadar metoksil sebesar 12,4\%. Berdasarkan kadar metoksil tersebut maka pektin yang dihasilkan dalam penelitian ini tergolong dalam pektin metoksil tinggi. Makin tinggi kadar metoksil dalam molekulnya, maka makin cepat pektin menjadi gel (Hariyanti, 2006).

\section{Kadar Asam Galakturonat}

Sifat fungsional pektin, seperti struktur dan tektur sangat ditentukan oleh kadar asam galakturonat serta muatan molekul pektin (Constenla dan Lozano, 2002). Mutu pektin tinggi salah satunya dilihat dari kadar galakturonat yang tinggi, yaitu minimal $35 \%$ sesuai yang dipersayaratkan oleh IPPA (International Pectin Producers Association).

Berdasarkan hasil analisis kadar asam galakturonat pada pektin kulit dan dami buah cempedak, didapatkan kadar asam galakturonat sebesar $71,6 \%$. Pektin yang dihasilkan dalam penelitian ini telah memenuhi nilai standar yang telah ditetapkan, disebabkan karena reaksi hidrolisis protopektin menjadi pektin yang komponen dasarnya asam D-galakturonat. Menurut Fitriani (2003) menyatakan bahwa selain asam galakturonat, pektin juga mengandung senyawa-senyawa non uronat, yaitu gula netral seperti Dgalaktosa, L-arabinosa dan L-ramnosa. Pada penggumpalan pektin, senyawasenyawa tersebut dapat terbawa dan mempengaruhi komposisi senyawa pektin yang dihasilkan. Perbedaan komposisi senyawa pektin mempengaruhi juga terhadap kadar galakturonat dipengaruhi oleh metode ekstraksi yang digunakan. Sebagian senyawa non uronat dapat dibebaskan dari pektin dengan cara pelarutan kembali pektin dalam air.

\section{Kadar Abu}

Kadar abu senyawa pektin hasil ektraksi menggambarkan jumlah dari senyawa anorganik yang masih terkandung. Berdasarkan hasil analisis kadar abu pada pektin kulit dan dami buah cempedak, didapatkan kadar abu sebesar $6 \%$. IPPA menentukan batas maksimum kadar abu pektin adalah tidak lebih dari $10 \%$, dengan demikian kadar abu hasil penelitian ini masih dibawah syarat maksimum yang telah ditetapkan. Hanum et al. (2012) melaporkan bahwa protopektin dalam buah dan sayuran terdapat dalam bentuk kalsiummagnesium pektat dan pektin dapat dibebaskan kalsium-magnesium dengan menggunakan pelarut asam. Peningkatan 
reaksi hidrolisis protopektin mengakibatkan bertambahnya komponen $\mathrm{Ca}^{2+}$ dan $\mathrm{Mg}^{2+}$ yang terlarut dalam larutan ekstrak dan ikut mengendap pada saat pengendapan pektin. Kadar kalsium dan magnesium yang banyak tentunya meningkatkan kadar abu dari pektin.

\section{Spektrum IR Pektin}

Hasil pengukuran spektrum FTIR menunjukkan kelompok gugus fungsi dan memberikan informasi struktural pektin hasil ekstraksi dari bahan baku limbah kulit dan dami buah cempedak. Daerah yang sering dianalisa dengan spektroskopi inframerah adalah dalam kisaran bilangan gelombang $4000-600 \quad \mathrm{~cm}^{-1}$.Identifikasi pengukuran fungsional pektin dilakukan dengan menggunakan spektrofotometer infra merah (FTIR), dengan rentang bilangan gelombang yang digunakan 4500-500 $\mathrm{cm}^{-1}$. Gugus fungsional utama pektin biasanya terletak pada area bilangan gelombang $1000-2000 \mathrm{~cm}^{-1}$ (Ismail et al., 2012). Ikatan karboksil teresterifikasi berada pada bilangan gelombang 1740-1760 $\mathrm{cm}^{-1}$ (Ismail et al., 2012).

Berdasarkan spektrum infra merah pektin (Gambar 3), serapan dari gugus hidroksil $(-\mathrm{OH})$ terdapat pada bilangan gelombang $3426 \mathrm{~cm}^{-1}$. Pada penelitian yang telah dilakukan oleh Fitria (2013) tentang karakterisasi pektin hasil ekstraksi kulit pisang kepok, gugus $-\mathrm{OH}$ terletak pada bilangan gelombang $3420,14 \mathrm{~cm}^{-1}$, dan Penelitian yang dilakukan oleh
(Madjaga et al., 2016) tentang ekstraksi pektin dari kulit buah sukun, spektrum -OH terletak pada bilangan gelombang $3412,08 \mathrm{~cm}^{-1}$. Hasil yang diperoleh diperkuat dengan pernyataan Pavia (2009), yang menyatakan spektrum $-\mathrm{OH}$ berada pada bilangan gelombang 3200 $3650 \mathrm{~cm}^{-1}$. Serapan pada bilangan gelombang 2954,95 $\mathrm{cm}^{-1}$ menunjukan vibrasi ulur gugus $\mathrm{C}-\mathrm{H}$ alkana. Pada penelitian yang telah dilakukan oleh Fitria (2013), gugus $\mathrm{C}-\mathrm{H}$ alkana terletak pada bilangan gelombang $2931,27 \mathrm{~cm}^{-1}$, dan Penelitian yang dilakukan oleh Madjaga et al. (2016), gugus C-H alkana berada pada bilangan gelombang 2927,94.

Penyerapan pada bilangan gelombang 1728 menunjukan adanya gugus - $\mathrm{C}=\mathrm{O}$ (karbonil). Sesuai dengan penelitian Vita (2013), gugus karbonil $(\mathrm{C}=\mathrm{O})$ terletak pada bilangan gelombang $1691,02 \mathrm{~cm}^{-1}$ dan penelitian yang telah dilakukan oleh Madjaga et al. (2016), gugus karbonil $(\mathrm{C}=\mathrm{O})$ terletak pada bilangan gelombang 1724,36 $\mathrm{cm}^{-1}$. Menurut Pavia (2009), bilangan gelombang gugus karbonil terletak pada kisaran bilangan gelombang $1630-1850$ $\mathrm{cm}^{-1}$.

Pita serapan pada bilangan gelombang $1396 \mathrm{~cm}^{-1}$ menunjukkan adanya ikatan - C-H. hal ini sesuai dengan penelitian Fitria (2013), ikatan - C-H terletak pada bilangan gelombang $1456,96 \mathrm{~cm}^{-1}$ dan penelitian dari Sufy (2015), menyatakan bahwa ikatan - C-H terletak pada bilangan gelombang 
1421,60 $\mathrm{cm}^{-1}$. Menurut Pavia (2009), pada kisaran bilangan gelombang 1450 bilangan gelombang ikatan - C-H terletak $1375 \mathrm{~cm}^{-1}$.

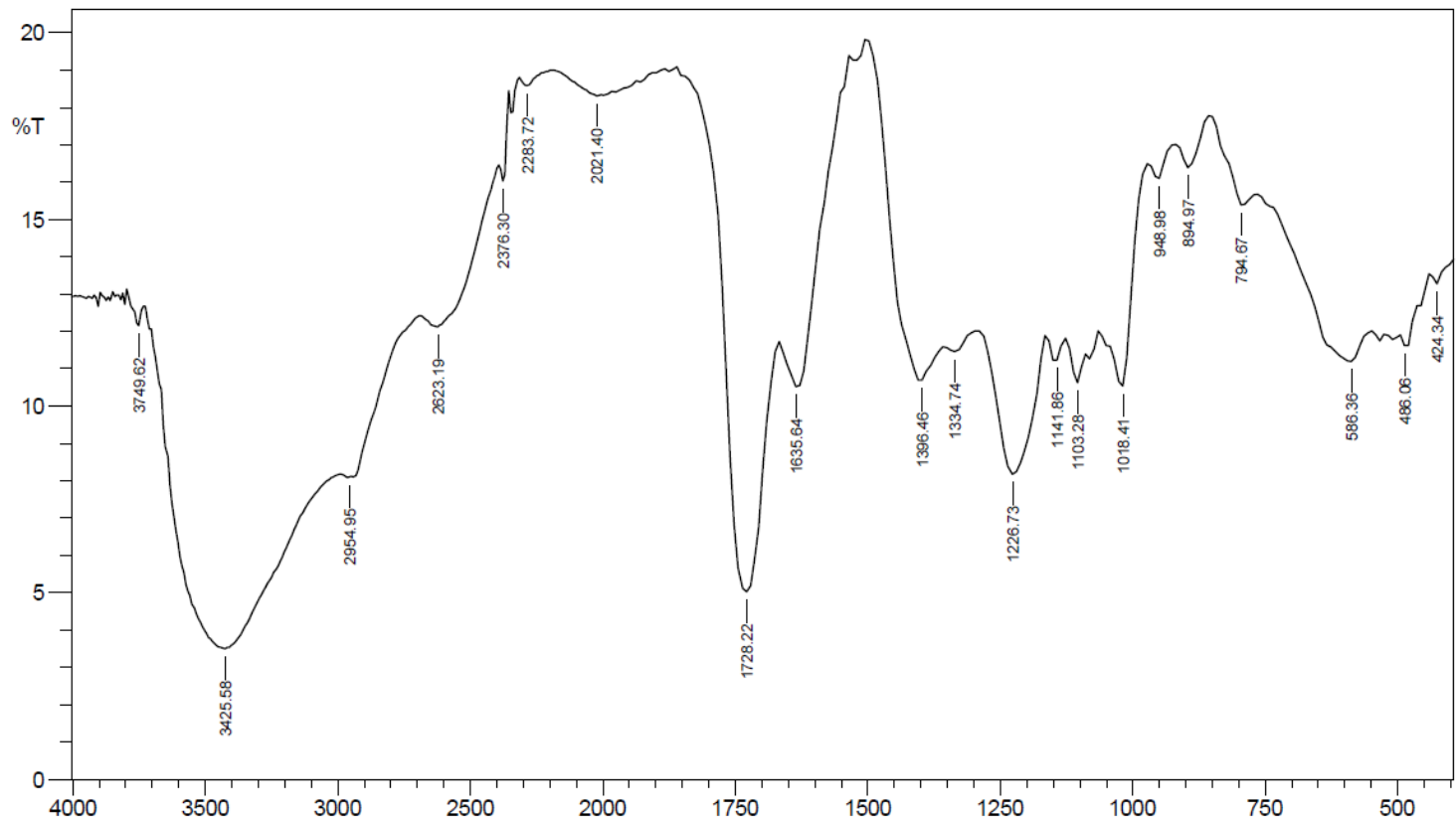

Gambar 3. Spektrum FTIR pektin kulit dan dami buah cempedak

Pita serapan pada bilangan gelombang $1227 \mathrm{~cm}^{-1}$, menunjukan ikatan dari eter (R-O-R) dari molekul pektin. Data didukung dengan penelitian Fitria (2013), bahwa spektra gugus eter berada panjang gelombang $1396,46 \mathrm{~cm}^{-1}$, pada penelitian Sufy (2015), gugus eter (R-O-R) berada pada panjang gelombang 1146,73 $\mathrm{cm}^{-1}$. Pavia (2009) menyatakan bahwa ikatan eter (R-O-R) berada pada kisaran spektrum 1050 - $1260 \mathrm{~cm}^{-1}$. Dari hasil gugus fungsional yang terukur dari spektrum FTIR dengan masing-masing serapan pada daerah panjang gelombang tertentu menunjukan kesesuaian dengan struktur pektin. Hal ini ditandai dengan terdapatnya vibrasi $\mathrm{OH}$, ikatan $-\mathrm{CH}_{3}$ pada cabang metoksil $\left(\mathrm{COOCH}_{3}\right)$, ikatan $\mathrm{C}-\mathrm{H}$, gugus karbonil $(-\mathrm{C}=\mathrm{O})$ dan gugus eter (-O-), (Vita, 2013).

\section{KESIMPULAN}

Jenis pelarut terbaik yang diperoleh pada ekstraksi pektin dari kulit dan dami buah cempedak, yaitu pelarut asam sitrat selama waktu 90 menit dengan rendemen pektin 34,65 \%. Karakteristik pektin meliputi kadar air 5\%, kadar abu $6 \%$, kadar metoksil 12,4 \%, dan kadar galakturonat $71,6 \%$.

\section{DAFTAR PUSTAKA}

Akhmalludin, K A. (2009). Pembuatan pektin dari kulit cokelat dengan cara ekstraksi. Skripsi. Semarang: Universitas Diponegoro.

Ardiansyah, G., Hamzah, F., dan Efendi, R. 2014. Variasi Tingkat Keasaman dalam EKstraksi Pektin KUlit Buah Durian. JOM FAPERTA. 1(2).

Arviani, 2009. Studi Perbandingan Metode Ekstraksi Pektin Pada Kulit Jeruk (Citrus Sp). [Skripsi]. Palu: Program Studi Kimia. Fakultas MIPA. Universitas Tadulako. 
Budiyanto, A., dan Yulianingsih. 2008. Pengaruh Suhu dan Waktu Ekstraksi Terhadap Karakter Pektin dari Ampas Jeruk Siam (Citrus nobilis L). Pascapanen. 5 (2) : 37-44

Evi, Z.N., Yuli, N., dan Rusdiansjah. 2013. Pengaruh Suhu dan Waktu Terhadap Hasil Ekstraksi Pektin dari Kulit Buah Nanas. Simposium Nasional RAPI XII. FT UMS : K 3943

Febriyanti, Y., Razak, A. R., dan Sumarni, N.K. 2018. Ekstraksi dan Karakterisasi Pektin dari Kulit Buah Kluwih (Artocarpus camansi Blanco). KOVALEN. 4(1) : 60-73.

Fitria, V. 2013. Karakterisasi Pektin Hasil Ekstraksi dari Limbah Kulit Pisang Kepok (Musa balbisiana ABB). [Skripsi]. Jakarta: Program Studi Farmasi. Fakultas Kedokteran dan IImu Kesehatan, Universitas Islam Negeri Syarif Hidayatullah.

Fitriani. 2003. Ekstraksi dan Karakterisasi Pektin dari Kulit Jeruk Lemon (Citrus medica Var Lemon). [Skripsi]. Bogor: Jurusan Teknologi Industri, FTP, IPB.

Goycoolea, F.M dan Adriana Cardenas. 2003. Pectins from Opuntia Spp : A Short Review. J.PACD-2003. Pages 17-29

Hanum, F., Kaban IMD., Tarigan, MA. 2012. Ekstraksi Pektin dari Kulit Buah Pisang Raja (Musa sapientum). Jurnal Teknik Kimia USU. 1(2).

Ismail, Norazelina sah Mohd, Ramli, Nazaruddin, Hani, Norziah Mohd, Meon, Zainudin. 2012. Ekstraction and Characterization of Pectin from Dragon Fruit (Hylocereus polyhizus) using Various Extraction Condition. Sains Malaysiana. 41(1): 41-45.

Madjaga. B.H., Nurhaeni, dan Ruslan. 2016. Optimalisasi Ekstraksi Pektin dari Kulit Buah Sukun (Artocarpus altilis). KOVALEN, 3(2):158-165.

Margani. A.D, Wignyanto dan Rahmah. N. L. 2012. Pelarut dan Lama Ekstraksi
Terbaik Dalam Pembuatan Pektin dari Limbah Buah Nangka (Jerami dan Kulit). https://www.scribd.com/document/3 19922686/Jurnal-Athika-DyahMargani, diakses pada tanggala 2 Juli 2017.

Nurhikmat, A. 2003. Ekstraksi Pektin dari Apel Lokal : Optimasi pH dan Waktu Hidrolisis. Widyariset, Vol. 4.

Nurviani. 2014. Ekstraksi Dan Karakterisasi Pektin Kulit Buah Pepaya (Carica papaya L.) Dari Beberapa Varietas. [Skripsi]. Palu: Program Studi Kimia. Fakultas MIPA. Universitas Tadulako.

Pavia. D., Lampman, G.M., Kriz, G.S., and Vyvyan, J.R. 2009. Introduction to Spectroscopy edition IV. Departement of Chemistry. Western Wasington University, belingham, Washington

Putra Kencana, N.I. 2010. Optimasi Proses Ekstraksi Pektin Dami Buah Nangka ( Artocarpus heterophyllus Lamk). Agritech. 30(3).158-163.

Pamona, S. 2013. Penggunaan Berbagai Jenis Asam Dalam Ekstraksi Pektin Kulit Buah Kakao Dari Beberapa Varietas Buah Kakao (Theobroma cacao, L). [Skripsi]. Palu: Jurusan Kimia. Fakultas Matematika dan Ilmu Pengetahuan Alam. Universitas Tadulako.

Rachmawan, A., Lestari D., Dwierra E., dan Djoko S. 2005. Ekstraksi dan Karakteristik Pektin dari Kulit Buah Kakao. Jurnal IImiah Pertanian Gakuryoku. 11(2): 190-194

Ranganna, S. 2000. Handbook of analysis and quality controlfor fruit and vegetable products second edition. New Delhi: Tata McGraw-Hill Publishing Company Limited.

Sufy, Q. 2015. Pengaruh Variasi Perlakuan Bahan Baku dan Konsentarsi Asam Terhadap Ekstraksi dan Karakteristik Pektin dari Limbah Kulit Pisang Kepok Kuning (Musa balbisiana BBB). [Skripsi]. Jakarta: Program Studi 
Farmasi. Fakultas Kedokteran dan IImu Kesehatan, Universitas Islam Negeri Syarif Hidayatullah.

Susilowati, Siswanto Munandar,Luluk Edahwati,Tutuk Harsini. 2013. Ekstraksi Pektin dari Kulit Buah Coklat dengan Pelarut Asam Sitrat. Eksergi. 11(1).

Windiarsi C., Nugroho, A.W., dan Argo, D.B. 2015. Optimasi Pektin Dari Kulit Buah Nangka (Artocarpus heterophyllus) Dengan Microwave Assisted Extraction (MAE) (Kajian Waktu Ekstraksi Dan Konsentrasi Pelarut). Bioproses Komoditas Tropis. 3(1),39-49. 